\title{
Adsorbing Ability of Soluble Heavy Metals In Acid Mine Drainage By Zeolite From Gedangsari Area, Gunungkidul Regency, Special Region of Yogyakarta
}

\author{
$1^{\text {st }}$ Rinaldy Mesakh Kase ${ }^{1}, 2^{\text {nd }}$ Doni Prakasa Eka Putra ${ }^{2}$ \\ rinaldy.mesakh.k@mail.ugm.ac.id ${ }^{1}$
}

Student of Geological Engineering Department, University of Gadjah Mada, Indonesia ${ }^{1}$
Lecturer of Geological Engineering Department, University of Gadjah Mada, Indonesia ${ }^{2}$

\begin{abstract}
Zeolite is a mineral which is presence quite abundant, especially in the Tegalrejo and surrounding areas, Gedangsari District, Gunungkidul Regency, Yogyakarta Special Region. This zeolite mineral is found in tuff claystone, tuffaceous sandstone and sandstone tuff. The cation exchange capability possessed by zeolites has long been of particular interest. This interest is proven through several previous studies to determine the cation exchange ability of zeolites. This research is important because it aims to identify the zeolite cation exchange capability of metal cations found in acid mine water samples. The cation exchange capability is carried out through a batch method which results are adjusted to the adsorption isotherm model. AAS analysis showed the sorbent sample had a $\mathrm{K}$ value of 0.243 with a maximum cation absorption value of $0.1681 \mathrm{mg}$ / $\mathrm{g}$ of zeolite samples for $\mathrm{Zn}$ cation (zinc); $\mathrm{K}$ value 0.116 with a maximum cation absorption value of $0.8836 \mathrm{mg} / \mathrm{g}$ zeolite sample in the copper cation. Adsorption of $\mathrm{Zn}$ and $\mathrm{Cu}$ cations by zeolite samples is in accordance with the Langmuir isotherm adsorption model. Measurement of the $\mathrm{pH}$ value shows an initial $\mathrm{pH}$ value of 5.2 to 5.4 changed to $7.36-7.46$ after the experiment. The results of the study concluded that zeolite can be used as an alternative to acid mine remediation, especially for $\mathrm{Cu}$ and $\mathrm{Zn}$ cation adsorption
\end{abstract}

Keyword: Mine Drainage, tuff claystone, tuffaceous sandstone and sandstone

\section{Introduction}

Water is the main source in life, without which there might be no life (Fetter, 2001). Every living individual needs to fulfill the need for water to survive. The need for water for the environment, especially humans, is the fulfillment of the necessities of life, related to the quality of water that is better than the quantity. Remediation of acid mine drainage becomes important with the main goal of reducing the amount of dissolved metal. Remediation can be done in various ways and tools, using zeolite is one of them (Putra et al., 2010; Warmada et al., 2010).

Acid mine drainage is characterized by AAS analysis then compared to the quality standard of waste water for gold or copper ore mining activities based on the Decree of the State Minister of Environment No. 202 of 2004. This study is still intended to determine the absorption ability of $\mathrm{Cu}$ and $\mathrm{Zn}$ metal cations in the characterized acid mine water samples.

\section{Experiment}

\subsection{Materials}

The samples of mine acid water used are acid mine water samples sent by P.T. Amman Mineral Nusa Tenggara. The acidity level of the water was measured using hanameter before 
the experiment showed the figures of 5.2-5.4. The metal cation value before the experiment shows varying numbers, namely: $\mathrm{Zn}$ value $0.7410 \mathrm{ppm} ; 0,5026 \mathrm{ppm} ; 0.5910 \mathrm{pmm}$ and $\mathrm{Cu}$ value $1.2613 \mathrm{ppm} ; 4,8226 \mathrm{ppm} ; 4,3369 \mathrm{ppm}$.

The adsorbent samples used are natural zeolites contained in tuffaceous siltstone lithology from Tegalrejo, Gunungkidul, DIY. Samples are crushed and sieved using a mesh sieve, taken in mesh numbers 100 to 200 then used directly without activation. XRD and SEM analysis (Figures 1 and 2) show that tuffaceous siltstone samples are composed of zeolite minerals in the form of mordenite.

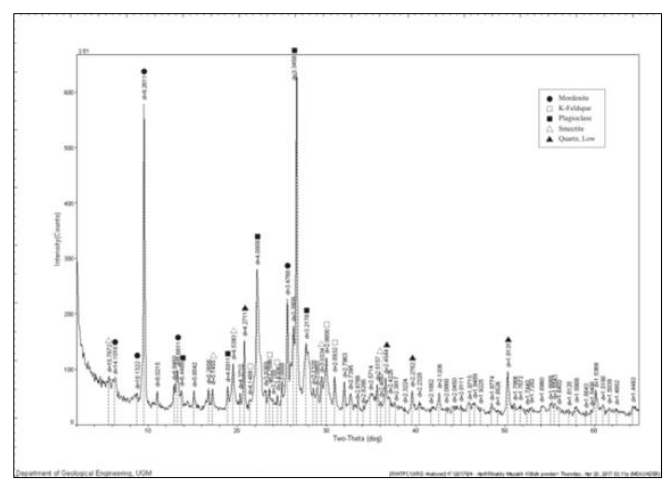

Fig. 1. Graph of XRD results on tuffaceous siltstone samples which indicate the presence of several mineral phases including mordenite.

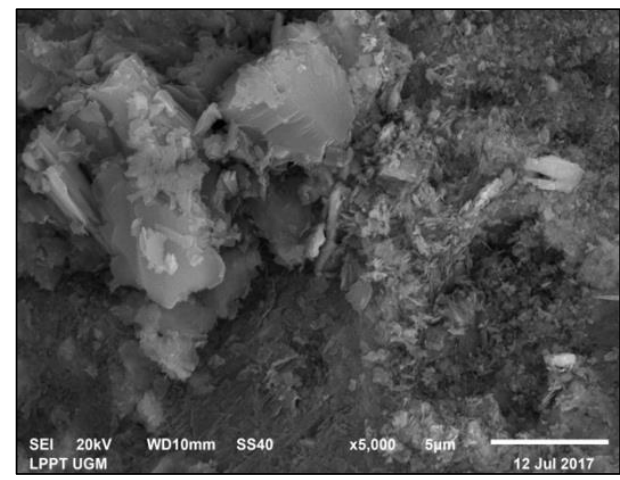

Figure 2. SEM results on tuffaceous silt samples which show mordenite (mor) with a fibrous shape.

\subsection{Batch Method Experiment}

Experiment with batch method was carried out 3 times to determine the ability of zeolite samples to absorb metal cations from acid mine drainage. Different amounts of adsorbent samples $(1 \mathrm{~g}, 2 \mathrm{~g}, 4 \mathrm{~g}, 8 \mathrm{~g}$, and $15 \mathrm{~g})$ were placed into $250 \mathrm{~mL}$ of acid mine drainage with an initial $\mathrm{pH}$ of 5.2 to 5.4. Acidic mine water solution that has been given zeolite is then stirred at a speed of $115 \mathrm{rpm}$ and the room temperature remains for 24 hours to reach equilibrium. Measurement of $\mathrm{Zn}$ and $\mathrm{Cu}$ metal cations after the experiment was carried out using the AAS method and the $\mathrm{pH}$ value was measured using a $\mathrm{pH}$ meter.

\section{Results and Discusion}

Data from the absorption of $\mathrm{Zn}$ and $\mathrm{Cu}$ into sorbent samples can be seen in Figures 3 and 4. The data shows that after 24 hours an equilibrium condition has been achieved with a variation in the weight gain of sorbent does not significantly affect the reduction of metal cations in the solution. The Langmuir adsorption isotherm model is adjusted to the data of the absorption of $\mathrm{Zn}$ and $\mathrm{Cu}$ metal cations into the sorbent sample by formula:

$$
C_{a d s}=\frac{Q^{o} K C_{\text {soln }}}{1+K C_{\text {soln }}}
$$

with Cads the $\mathrm{Zn}$ concentration adsorbed into the sorbent sample divided by sorbent (mg / gr), $\mathrm{Q}^{\circ}$ is the maximum ability of every gram of zeolite to adsorb metal cations ( $\left.\mathrm{mg} / \mathrm{gr}\right), \mathrm{K}$ is the absorption coefficient of metal cations from the dissolved phase in the sample into solid phase zeolite sample as sorbent, and Csoln is the final concentration of metal in solution. 


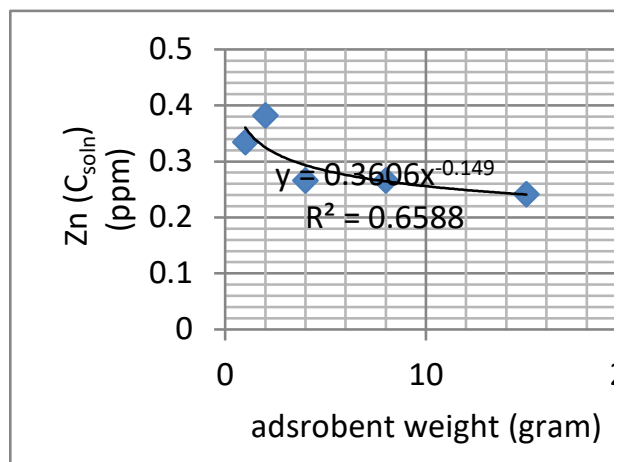

Fig. 3. The adsorption of $\mathrm{Zn}$ cation in the sorbent sample which occurs for 24 hours at a fixed temperature with varying adsorbent weight.

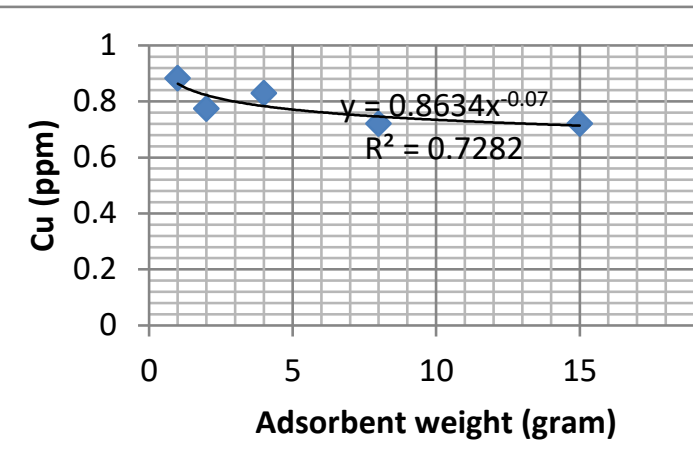

Fig. 4. The adsorption of $\mathrm{Cu}$ cation in the sorbent sample which occurs for 24 hours at a fixed temperature with varying adsorbent weight.

The Langmuir model is suitable for the data of $\mathrm{Zn}$ metal cation absorption into the sorbent sample with $\mathrm{R}^{2}$ is 0.5805 and the absorption of $\mathrm{Cu}$ metal into the sorbent sample with $\mathrm{R}^{2}$ is 0.6223 . The maximum ability of sorbent samples to absorb $\mathrm{Zn}$ is $0.1681 \mathrm{mg} / \mathrm{g}$ zeolite with a $\mathrm{K}$ value of 0.243 . The maximum ability of sorbent samples to absorb $\mathrm{Cu}$ is $0.8836 \mathrm{mg} /$ $\mathrm{g}$ zeolite with a $\mathrm{K}$ value of 0.116 (Figures 5, 6, 7 and 8). The $\mathrm{Q}^{\circ}$ and $\mathrm{K}$ values are then entered into equation (1) so as to produce an absorption equation for each metal cation into the sorbent sample.

$\mathrm{Zn}$ metal cations are adsorbed following the equation:

$$
\begin{gathered}
C_{\text {ads }}=\frac{Q^{o} K C_{\text {soln }}}{1+K C_{\text {soln }}} \\
C_{\text {ads }}=\frac{0,1681 K C_{\text {soln }}}{1+K C_{\text {soln }}} \\
C_{\text {ads }}=\frac{0,16810,243 C_{\text {soln }}}{1+0,243 C_{\text {soln }}} \\
C_{\text {ads }}=\frac{0.0408483 C_{\text {soln }}}{1+0,243 C_{\text {soln }}}
\end{gathered}
$$

$\mathrm{Cu}$ metal cations are adsorbed following the equation:

$$
\begin{gathered}
C_{\text {ads }}=\frac{Q^{o} K C_{\text {soln }}}{1+K C_{\text {soln }}} \\
C_{\text {ads }}=\frac{0,8836 K C_{\text {soln }}}{1+K C_{\text {soln }}} \\
C_{\text {ads }}=\frac{0,88360,116 C_{\text {soln }}}{1+0,243 C_{\text {soln }}} \\
C_{\text {ads }}=\frac{0.1024976 C_{\text {soln }}}{1+0,243 C_{\text {soln }}}
\end{gathered}
$$

Analysis of variations in zeolite sample weight as sorbents showed that weight gain from 4 $\mathrm{g}$ to $8 \mathrm{~g}$ then $15 \mathrm{~g}$ into $250 \mathrm{~mL}$ of acid mine drainage did not significantly influence the absorption of $\mathrm{Zn}$ and $\mathrm{Cu}$ metal cations from acid mine drainage. 


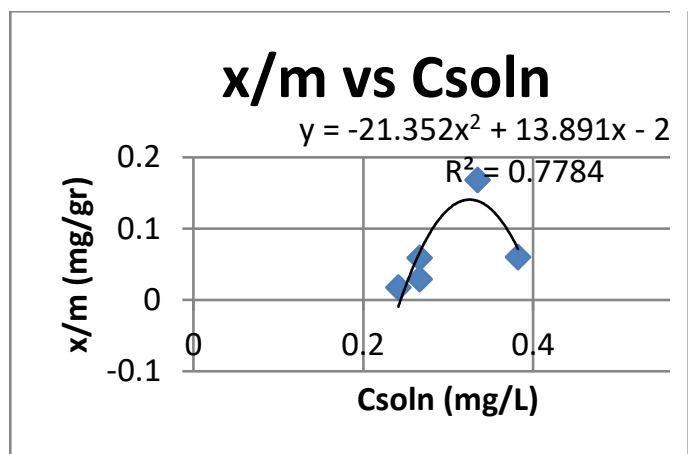

Fig. 5. Plot of the $\mathrm{Zn}$ adsorption value into the sorbent sample which shows the suitability of the data with the Langmuir adsorption model.

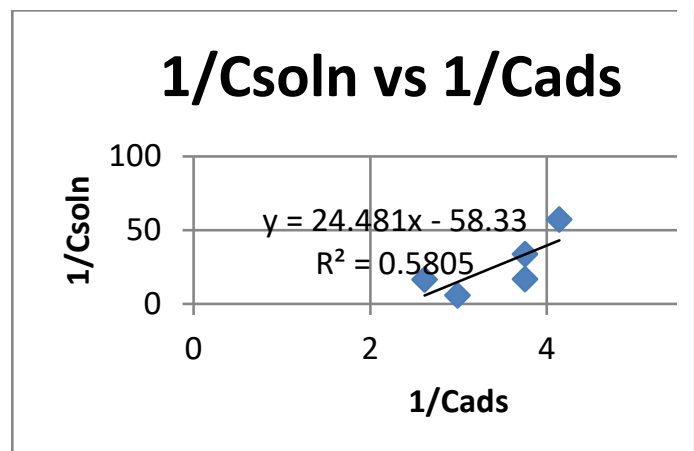

Fig. 7. Form of linearisation of Cads and Csoln values on the absorption of $\mathrm{Zn}$ cations showing the suitability of the Langmuir model to the data.

\section{$x / m$ vs Csoln}

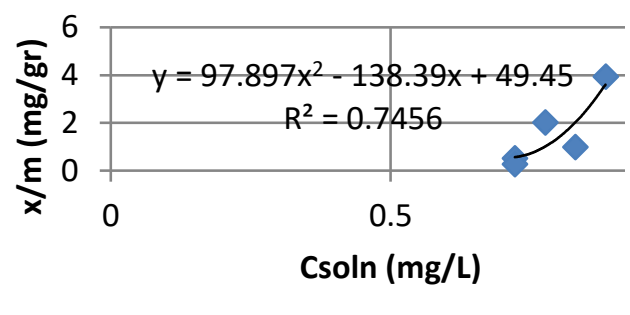

Fig. 6. Plot of the $\mathrm{Cu}$ adsorption value into the sorbent sample which shows the suitability of the data with the Langmuir adsorption model

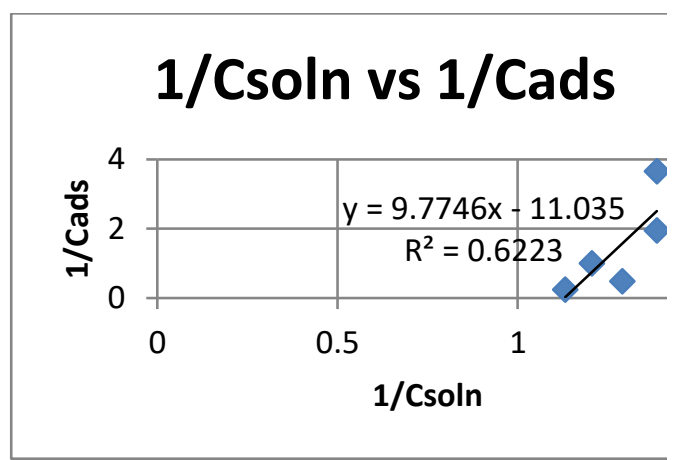

Fig. 8. Form of linearisation of Cads and Csoln values on the absorption of $\mathrm{Cu}$ cations showing the suitability of the Langmuir model to the data.

\section{Conclusion}

This study then concluded that tuffaceous siltstone samples from the Tegalrejo region had a composition of zeolite (mordenite) which was good for use as a sorbent on $\mathrm{Cu}$ and $\mathrm{Zn}$ cations. The maximum absorption ability of $\mathrm{Cu}$ is $0.8836 \mathrm{mg} / \mathrm{g}$ zeolite greater than the absorption capacity of $\mathrm{Zn}$ which is $0.1681 \mathrm{mg} / \mathrm{g}$ zeolite based on the Langmuir equation. The weight of the sample sorbent used if more than $4 \mathrm{~g}$ per $250 \mathrm{~mL}$ of acid mine drainage does not have a significant effect on the absorption of $\mathrm{Cu}$ and $\mathrm{Zn}$ metal cations. 


\section{References}

[1] Fetter, C.W., 2004, Applied Hydrogeology, Fourth Edition, New Jersey: Prentice Hall.

[2] Putra, D.P.E., Wilopo, W., Haryono, S.N., Warmada, I W., dan Hirajima, T., 2010, Copper Removal From Water Using Natural Zeolite From Gedangsari, Gunungkidul, Yogyakarta, Journal SE Asian Applied Geology May-Aug 2010, Vol 2(2) pp 117-120.

[3] Warmada, I W., Pich, B., Hendrayana, H., dan Yoneda, T., 2010, Modified Natural Zeolite And Bentonite As Adsorbents Of Heavy Metal Ions From Polluted Groundwater In Yogyakarta Urban Area, Indonesia, Journal SE Asian Applied Geology Jan-Apr 2010, Vol 2(1) pp 12-19. 